\title{
Repurposing of CNS drugs to treat COVID-19 infection: targeting the sigma-1 receptor
}

\author{
Kenji Hashimoto ${ }^{1}$ (1)
}

Received: 24 November 2020 / Accepted: 19 December 2020 / Published online: 5 January 2021

(c) Springer-Verlag GmbH, DE part of Springer Nature 2021

\begin{abstract}
The novel coronavirus disease 2019 (COVID-19) is caused by severe acute respiratory syndrome coronavirus 2 (SARS$\mathrm{CoV}-2$ ). The escalating number of SARS-CoV-2-infected individuals has conferred the viral spread with the status of global pandemic. However, there are no prophylactic or therapeutic drugs available on the market to treat COVID-19, although several drugs have been approved. Recently, two articles using the comparative viral-human protein-protein interaction map revealed that the sigma-1 receptor in the endoplasmic reticulum plays an important role in SARS-CoV-2 replication in cells. Knockout and knockdown of SIGMARI (sigma-1 receptor, encoded by SIGMARI) caused robust reductions in SARS-CoV-2 replication, which indicates that the sigma-1 receptor is a key therapeutic target for SARS-CoV-2 replication. Interestingly, a recent clinical trial demonstrated that treatment with the antidepressant fluvoxamine, which has a high affinity at the sigma-1 receptor, could prevent clinical deterioration in adult outpatients infected with SARS-CoV-2. In this review, we discuss the brief history of the sigma-1 receptor and its role in SARS-CoV-2 replication in cells. Here, we propose repurposing of traditional central nervous system (CNS) drugs that have a high affinity at the sigma-1 receptor (i.e., fluvoxamine, donepezil, ifenprodil) for the treatment of SARS-CoV-2-infected patients. Finally, we discussed the potential of other CNS candidates such as cutamesine and arketamine.
\end{abstract}

Keywords Endoplasmic reticulum $\cdot$ Replication $\cdot$ Sigma-1 receptor

\section{Introduction}

The coronavirus disease 2019 (COVID-19) is an acute respiratory disease that is caused by the novel RNA virus SARS-CoV-2. After SARS-CoV-2 was detected in Wuhan, China, in December 2019, the number of individuals infected with SARS-CoV-2 has markedly increased worldwide. On December 16, 2020, a report from Johns Hopkins University Coronavirus Resource Center showed that the number of global cases and global deaths were 73,992,814 and $1,645,136$, respectively. As we approach 2021 , various regions are experiencing a second or third wave of COVID19 infections. Therefore, we are under pressure to develop prophylactic and therapeutic drugs for COVID-19-infected individuals as soon as possible. Clinical trials of a number

Kenji Hashimoto

hashimoto@faculty.chiba-u.jp

1 Division of Clinical Neuroscience, Chiba University Center for Forensic Mental Health, 1-8-1 Inohana, Chiba 260-8670, Japan of candidate drugs to treat COVID-19 are currently underway [1-3].

Drug repurposing is a promising approach for the COVID-19 pandemic because of the speed and low cost required for development and approval [4-8]. Accumulating evidence suggests that SARS-CoV-2 infection has deleterious effects in the central nervous system (CNS), which can result in psychiatric and neurological symptoms in infected individuals [9-13]. In addition, the risk for neurodevelopmental disorders such as autism spectrum disorder in offspring of COVID19-infected pregnant women has been discussed $[14,15]$.

On November 12, 2020, Lenze et al. [16] demonstrated that the antidepressant fluvoxamine (Fig. 1), which is a CNS drug with high affinity at the sigma-1 receptor, could prevent clinical deterioration in adult outpatients infected with SARS-CoV-2. The pilot data indicates that it is critical to prevent SARS-CoV-2-infected individuals from deteriorating to severe illness [17], although further trials using a larger sample size are needed. 
<smiles>COCCCC/C(=N\OCCN)c1ccc(C(F)(F)F)cc1</smiles>

Fluvoxamine<smiles>COc1cc2c(cc1OC)C(=O)C(CC1CCN(Cc3ccccc3)CC1)C2</smiles>

Donepezil<smiles>CC(C(O)c1ccc(O)cc1)N1CCC(Cc2ccccc2)CC1</smiles>

Ifenprodil

Fig. 1 Chemical structure of fluvoxamine, donepezil, and ifenprodil

In this review, the author evaluates a brief history of the endoplasmic reticulum (ER) protein sigma-1 receptor and the role of the sigma-1 receptor in the replication of SARS-CoV-2 in cells. Finally, we propose that traditional CNS drugs with sigma-1 receptor agonism are potential prophylactic drugs for the treatment of SARS-CoV-2-infected individuals.

\section{Endoplasmic reticulum stress due to SARS-CoV-2 replication}

SARS-CoV-2 enters cells via the spike glycoprotein through a process called endocytosis. Subsequent SARS$\mathrm{CoV}-2$ replication takes place in an endoplasmic reticulum (ER)-derived intermediate compartment in the

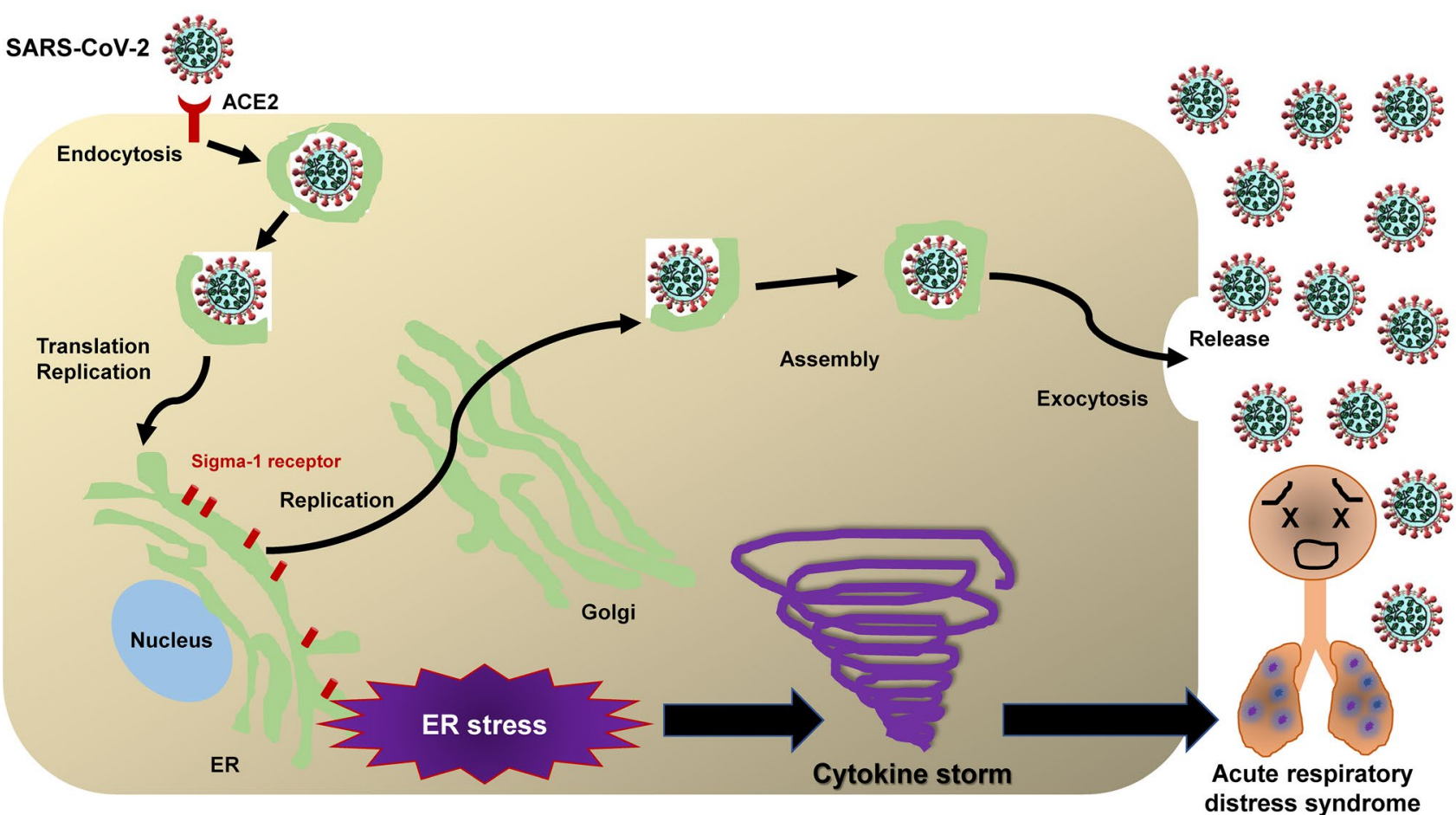

Fig. 2 Role of the sigma-1 receptor in the ER and ER stress during the replication cycle of SARS-CoV-2 in cells. SARS-CoV-2 binds to the ACE2 (angiotensin-converting enzyme 2) receptor on the surface of cells via spike proteins, which subsequently triggers endocytosis. Subsequent SARS-CoV-2 replication takes place in an ER-derived intermediate compartment of the ER-Golgi. It has been suggested that ER stress due to the replication of SARS-CoV-2 may contribute to inflammatory events (i.e., cytokine storm), which results in severe symptoms of acute respiratory distress syndrome, accompanied by high mortality. The sigma- 1 receptor in the ER plays a key role in the replication of SARS-CoV-2 in cells [41, 42]. A slight modification is shown in this figure, from Zhang et al. [1] 
ER-Golgi (Fig. 2) [1, 18]. It has been suggested that ER stress due to the replication of SARS-CoV-2 may contribute to inflammatory events (i.e., cytokine storm), which results in severe symptoms of acute respiratory distress syndrome accompanied by high mortality (Fig. 2) [1, 18-21]. A case control study showed higher levels of ER stress markers [i.e., glucose regulated protein 78 (GRP78), C/EBP homologous protein (CHOP), phosphoextracellular signal regulated kinase (PERK)] in SARSCoV-2 positive subjects [22]. Collectively, it is possible that ER could be a potential therapeutic target for the management of SARS-CoV-2 infection [20, 23].

\section{Brief history of the sigma-1 receptor}

In 1976, Dr. Martin et al. initially proposed that the sigma receptor is a subtype opioid receptor that mediates the unique psychotomimetic effects of the prototypic drug SKF-10, 047 ( $N$-allyl-normetazocine) [24]. Subsequently, in 1982, Dr. Su [25] reported the specific binding site of $\left[{ }^{3} \mathrm{H}\right](+)$ SKF-10, 047, which was proven to be resistant to opioid receptor antagonists (i.e., naloxone and naltrexone). Typical antipsychotic haloperidol had very high affinity $\left(\mathrm{IC}_{50}=7.0 \mathrm{nM}\right)$ at $\left[{ }^{3} \mathrm{H}\right] \mathrm{SKF}-10,047$ binding to the sigma receptor [25]. The binding sites reported by Dr. Su were later termed "sigma receptors" to distinguish them from classical opiate receptors. Receptor binding studies show the existence of at least two subtypes, sigma-1 and sigma-2 receptors.

In 1997, the sigma-1 receptor, a single polypeptide composed of 223 amino acids, was cloned. This receptor contains an ER-retention signal [26]. In 2007, Hayashi and $\mathrm{Su}$ [27] reported that the sigma-1 receptor could function as a novel ER molecular chaperone, which regulates a variety of cellular functions. In this assay, sigma-1-receptor agonists (i.e., fluvoxamine, fluoxetine) promote dissociation of the sigma-1 receptor from another ER chaperone, BiP/GRP78, which results in sigma-1-receptor chaperone activity in the cells. In contrast, sigma-1-receptor antagonists (i.e., haloperidol, NE-100) reinforce the association, thereby blocking the action of sigma1-receptor agonists [27, 28]. In 2017, a sigma-2 receptor was identified as TMEM97 (transmembrane protein 97 or MAC30), which is an ER-resident transmembrane protein [29].

Substantial evidence suggests that the sigma- 1 receptor plays a role in the pathophysiology of a number of psychiatric and neurodegenerative disorders, and that sigma-1 receptor agonists have beneficial effects in a number of CNS disorders [30-40].

\section{Role of the sigma-1 receptor in SARS-CoV-2 replication}

On April 30, 2020, a study using the SARS-CoV-2-human protein-protein interaction map identified 332 high-confidence protein-protein interactions between SARS-CoV-2 and human proteins [41]. Interestingly, multiple compounds for sigma-1 and sigma-2 receptors were identified as promising inhibitors of SARS-CoV-2 replication [41]. Sigma-1 receptor ligands include chloroquine, clemastine, dextromethorphan, haloperidol, E-52862, PB28, PD-144418, and RS-PPCC. Sigma-2 receptor ligands include clemastine, chloroquine, haloperidol, PB28, PD-144418, and RS-PPCC. In this assay, PB28 was approximately 20 times more potent than hydroxychloroquine.

On October 15, 2020, the same group [42] identified the sigma-1 receptor (encoded by SIGMARI) as a functional host-dependency factor for SARS-CoV-2. They demonstrated that knockout or knockdown of SIGMAR1, but not SIGMAR2 (also known as TMEM97), caused robust reductions in SARS-CoV-2 replication, which indicates that the sigma-1 receptor is a key target for SARS-CoV-2 replication. In this study, they compared three typical antipsychotics (haloperidol, fluphenazine, chlorpromazine) in a SARS$\mathrm{CoV}$-2-inhibition assay. The order of inhibitory effects for SARS-CoV-2 is chlorpromazine $\left(\mathrm{pIC}_{50}=6.050\right)>$ fluphenazine $\left(\mathrm{pIC}_{50}=6.460\right)>$ haloperidol $\left(\mathrm{pIC}_{50}=5.684\right)$ [42] However, the order of binding affinity of these compounds at the sigma-1 receptor was haloperidol $(\mathrm{Ki}=4 \mathrm{nM})>$ fluphenazine $(\mathrm{Ki}=17 \mathrm{nM})>$ chlorpromazine $(\mathrm{Ki}=180 \mathrm{nM})$ [43]. Thus, the potency of these compounds for inhibiting SARSCoV-2 replication was not associated with their potency for the sigma-1 receptor. Since haloperidol is a potent sigma1-receptor antagonist $[27,28]$, it is unclear whether blockage at the sigma- 1 receptor may contribute to antiviral activity for SRAS-CoV-2.

In the preliminary analysis, the outcome of users treated with typical antipsychotics (i.e., haloperidol, chlorpromazine, fluphenazine) with high or moderate affinity at the sigma-1 receptor was better than that of users treated with atypical antipsychotics (i.e., aripiprazole, olanzapine, quetiapine, risperidone, brexpiprazole, paliperidone) without sigma-1 receptor affinity [42]. From the data, we cannot conclude that typical antipsychotics have beneficial effects to prevent clinical deterioration in SARS-CoV-2-infected patients, although the data is attracting support. A further randomized control study using typical antipsychotic haloperidol (a potent sigma-1-receptor antagonist) and atypical antipsychotic without sigma-1 receptor affinity is needed.

Nonetheless, the two articles that were published in Nature and Science strongly encourage the use of the 
sigma-1 receptor compounds for COVID-19-infected patients, since a number of CNS drugs have been reported to bind at the sigma-1 receptor with high to moderate affinity [41, 42, 44]. However, which pharmacological activity (i.e., agonist or antagonist) of sigma-1-receptor ligands is responsible for the activity of SARS-CoV-2 replication remains uncertain.

\section{Haloperidol and other antipsychotics}

Typical antipsychotics such as haloperidol $(\mathrm{Ki}=4 \mathrm{nM})$, perphenazine $(\mathrm{Ki}=12 \mathrm{nM})$, fluphenazine $(\mathrm{Ki}=17 \mathrm{nM})$, trifluoperazine $(\mathrm{Ki}=67 \mathrm{nM})$, pimozide $(\mathrm{Ki}=144 \mathrm{nM})$, chlorpromazine $(\mathrm{Ki}=180 \mathrm{nM})$, and triflupromazine $(\mathrm{Ki}=214 \mathrm{nM})$ have high to moderate affinity at the sigma-1 receptor [43]. Although haloperidol is a potent sigma-1-receptor antagonist, the pharmacological activity (antagonist or agonist) of other antipsychotics (i.e., chlorpromazine) are unclear. In contrast, atypical antipsychotics, such as clozapine and olanzapine, do not bind to the sigma-1 receptor [43]. Atypical antipsychotics, such as olanzapine, aripiprazole, paliperidone, risperidone, and quetiapine, did not show antiviral activity [41, 42].

A randomized clinical trial of chlorpromazine following the standard therapeutic protocol in adult subjects $(n=40)$ with moderate-type COVID-19 (WHO-OSCI 3-5) (ClinicalTrials.gov Identifier: NCT04366739) is underway in Paris, France. Furthermore, a single-blind, randomized clinical trial of chlorpromazine following the standard therapeutic protocol in adult subjects $(n=100)$ with COVID-19 (ClinicalTrials.gov Identifier: NCT04354805) is underway in Cairo, Egypt. There is high anticipation for results to become available in the near future.

It is well known that typical antipsychotics such as haloperidol can produce extrapyramidal side effects due to potent dopamine- $\mathrm{D}_{2}$-receptor antagonism. In addition, the repeated use of haloperidol might cause upregulation of the dopamine- $\mathrm{D}_{2}$ receptor in the brain, thus resulting in dopamine supersensitivity [45]. Considering these factors, it is unlikely that haloperidol is a suitable drug for patients with SARS$\mathrm{CoV}-2$, despite its potent sigma-1-receptor antagonism. If a sigma-1-receptor antagonist is better for blocking SARSCoV-2 replication than a sigma-1-receptor agonist, the selective sigma-1 receptor antagonist NE-100 without dopamine$\mathrm{D}_{2}$ receptor antagonism may be suitable, as indicated by the phase I/II study performed by Taisho Pharmaceutical Co. Ltd (Tokyo, Japan) [46].

\section{Fluvoxamine and other antidepressants}

Antidepressants such as selective serotonin reuptake inhibitors (SSRIs) and serotonin and norepinephrine reuptake inhibitors (SNRIs) have been used in the treatment of a number of psychiatric disorders, such as depression and anxiety. In 1996, we demonstrated that some SSRIs, such as fluvoxamine, sertraline, fluoxetine, and citalopram, have high to moderate affinity at sigma- 1 receptors in the rat brain (Table 1) [47]. In 2014, we reported the binding affinity of new antidepressants, including SNRIs (duloxetine, venlafaxine, milnacipran), and mirtazapine (a noradrenaline and specific serotonergic antidepressant), at the sigma-1 receptor [48]. The order of potency for SSRIs at the sigma-1 receptor was as follows: fluvoxamine $>$ sertraline $>$ fluoxetine $>$ escitalopram $>$ citalopram $>$ paroxetine (Table 1). SNRIs and mirtazapine showed very weak affinity at the sigma-1 receptor (Table 1). Furthermore, fluvoxamine, fluoxetine, and escitalopram significantly potentiated nerve growth factor (NGF)-induced neurite outgrowth in PC12 cells, and the effects of these SSRIs were antagonized by NE-100 [48, 49]. Moreover, the effects of fluvoxamine and fluoxetine on NGFinduced potentiation of neurite outgrowth were antagonized by sertraline, which suggests that sertraline may be a sigma1-receptor antagonist [48].

Using an in vivo mouse model, we demonstrated that fluvoxamine improved phencyclidine (PCP)-treated cognitive deficits in mice via sigma-1-receptor activation, whereas sertraline and paroxetine did not improve PCP-treated cognitive deficits in the model $[50,51]$. These findings suggest that fluvoxamine and sertraline might function as an agonist and antagonist, respectively, at the sigma-1 receptor. Several clinical studies demonstrated the beneficial effects of fluvoxamine on cognitive impairments in schizophrenia patients [52-55]. Collectively, fluvoxamine is the most

Table 1 Affinity of the antidepressants for sigma-1 receptor in rat brain

\begin{tabular}{lll}
\hline Antidepressants & Ki $(\mathrm{nM})$ & Action \\
\hline Fluvoxamine (SSRI) & $36^{\mathrm{a}}$ or $17.0^{\mathrm{b}}$ & Agonist \\
Sertraline (SSRI) & $57^{\mathrm{a}}$ or $31.6^{\mathrm{b}}$ & Antagonist \\
Fluoxetine (SSRI) & $240^{\mathrm{a}}$ or $191.2^{\mathrm{b}}$ & Agonist \\
Escitalopram (SSRI) & $288.3^{\mathrm{b}}$ & Agonist \\
Citalopram (SSRI) & $292^{\mathrm{a}}$ or $403.8^{\mathrm{b}}$ & n.d. \\
Imipramine (TCA) & $343^{\mathrm{a}}$ & Agonist \\
Desipramine (TCA) & $1987^{\mathrm{a}}$ & \\
Paroxetine (SSRI) & $1893^{\mathrm{a}}$ or $2041^{\mathrm{b}}$ & \\
Duoxetine (SNRI) & $3533^{\mathrm{b}}$ & \\
Venlafaxine (SNRI) & $>10,000^{\mathrm{b}}$ & \\
Milnacipran (SNRI) & $>10,000^{\mathrm{b}}$ & \\
Mirtazapine (NaSSA) & $>10,000^{\mathrm{b}}$ & \\
\hline
\end{tabular}

SSRI selective serotonin reuptake inhibitor, SNRI serotonin and noradrenaline reuptake inhibitor, TCA tricyclic antidepressant, NaSSA noradrenaline and specific serotonergic antidepressant, $n . d$. not determined

${ }^{a}$ Narita et al. [47]

${ }^{\mathrm{b}}$ Ishima et al. [48] 
potent sigma-1-receptor agonist among the currently available antidepressants.

A positron emission tomography (PET) study using $\left[{ }^{11} \mathrm{C}\right]$ SA4503 revealed that oral administration of fluvoxamine (50-200 mg) bound to sigma-1 receptors in the human brain, thus indicating that fluvoxamine in therapeutic doses binds to sigma-1 receptors [56]. These findings show that activation at the sigma-1 receptor is involved in the pharmacological action of fluvoxamine in humans [32-35, 57].

\section{Fluvoxamine for ICU patients or sepsis}

Delirium is a highly prevalent disorder among older patients in intensive care units (ICUs). Furuse and Hashimoto [58] reported five cases elucidating the beneficial effects of fluvoxamine on delirium in ICU patients, such as acute aortic dissociation, traumatic subarachnoid hemorrhage, brain contusion, sepsis by pyelonephritis, cerebral infarction, pulmonary emphysema, and severe pneumonia. Although fluvoxamine showed beneficial effects in ICU patients, its mechanisms of action cannot be determined from these cases.

In 2019, Rosen et al. [59] reported that the sigma-1 receptor in the ER is essential for the production of cytokine in a mouse model of septic shock and that fluvoxamine could protect against inflammatory response and lethal septic shock. Sigmarl knock-out (KO) mice showed increased mortality after administration of a sub-lethal dose $(5 \mathrm{mg} /$ $\mathrm{kg}$ ) of lipopolysaccharide (LPS) compared to wild-type mice, indicating that sigma-1 receptor can attenuate systemic inflammation [59]. Furthermore, fluvoxamine significantly improved the clinical score in a sepsis model, and it enhanced survival in LPS-treated mice [59]. Collectively, this study strongly suggests that the potent sigma-1-receptor agonist fluvoxamine could ameliorate inflammatory events (i.e., cytokine storm) associated with ER stress due to SARS-CoV-2 replication (Figs. 2, 3).

\section{Fluvoxamine for SARS-CoV-2-infected outpatients}

On November 12, 2020, Lenze et al. [16] published an article on the prevention of clinical deterioration using fluvoxamine in adult outpatients infected with SARS-CoV-2. In the trial, none of the fluvoxamine group $(n=80)$ met the respiratory deterioration criteria compared to the six patients in the placebo group $(n=72)$. This study used a small sample size; thus, further trial using a large sample size is strongly encouraged. A fully-remote, randomized placebo-controlled clinical trial of fluvoxamine in adult subjects $(n=880)$ with
COVID-19 (ClinicalTrials.gov Identifier: NCT04668950) is underway by the same group.

In this trial, fluvoxamine was selected due to its potent sigma-1-receptor agonism [16]. Given the role of the chaperone activity of the ER sigma-1 receptor agonist, it is possible that the potent sigma-1-receptor activity of fluvoxamine could contribute to beneficial actions in these patients. However, from the current trial, we cannot prove the contribution of fluvoxamine sigma-1-receptor agonism to beneficial actions in patients infected with SARS-CoV-2. Therefore, a clinical trial of fluvoxamine versus sertraline (or paroxetine) in patients infected with SARS-CoV-2 is needed to confirm the role of sigma-1-receptor agonism. Importantly, the advantages of fluvoxamine are safety, low cost, and oral administration.

\section{Donepezil}

Donepezil (Fig. 1), which is a potent acetylcholinesterase (AChE) inhibitor, has been widely used to treat Alzheimer's disease (AD). In addition to AChE inhibition, donepezil binds to sigma receptors, including sigma-1 and sigma-2 receptors [60]. We reported that donepezil could potentiate NGF-induced neurite outgrowth in PC12 cells and that NE-100 significantly blocked donepezil-induced potentiation of NGF-induced neurite outgrowth [61]. Furthermore, donepezil improved PCP-induced cognitive deficits in mice through sigma-1 receptor activation [62]. Moreover, a PET study using $\left[{ }^{11} \mathrm{C}\right] \mathrm{SA} 4503$ showed that oral administration of donepezil $(5 \mathrm{mg}$ and $10 \mathrm{mg}$ ) bound to the sigma-1 receptor in the human brain with occupancies of approximately $60 \%$ and approximately $75 \%$, respectively [63]. These findings suggest that activation at the sigma- 1 receptor is involved in the pharmacological action of donepezil in humans. It is, therefore, of interest to investigate a follow-up study of AD patients treated with or without donepezil after confirming SARS-CoV-2 infection.

\section{Ifenprodil}

Ifenprodil has been used as a cerebral vasodilator in a limited number of countries, including Japan and France. Ifenprodil is known to be a prototypical antagonist of the GluN2B subunit of the $N$-methyl-D-aspartate receptor (NMDAR) (Fig. 1). In addition to its antagonism at the $\alpha 1$ adrenergic receptor and NMDAR, ifenprodil binds to sigma-1 and sigma-2 receptors with high affinity [64-66]. Furthermore, ifenprodil significantly potentiated NGF-induced neurite outgrowth in PC12 cells [67]. In contrast, the $\alpha 1$ adrenergic receptor antagonist, prazosin, and the NMDAR GluN2B antagonist Ro 25-6981 did 


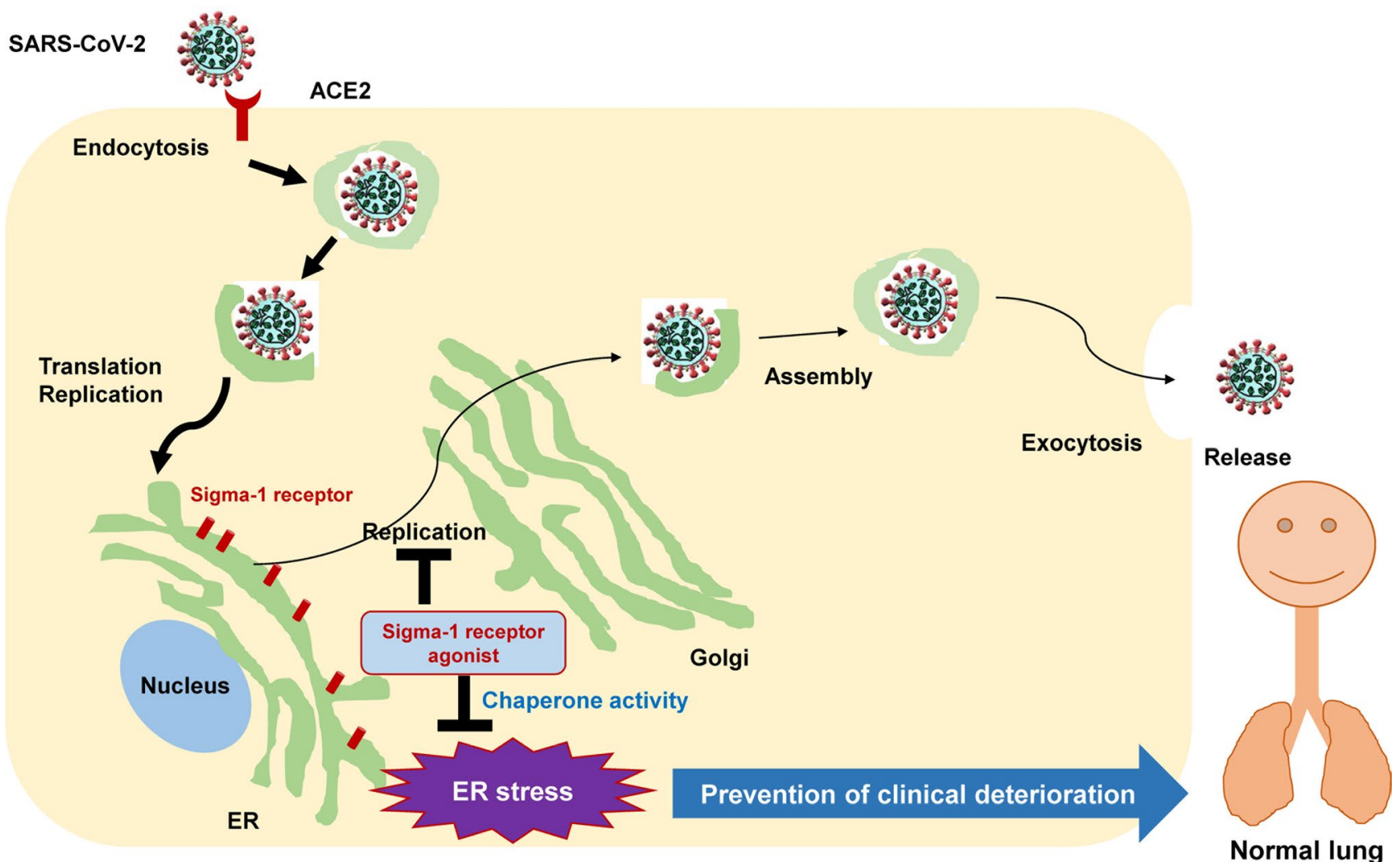

Fig. 3 Proposed scheme for prophylactic effects of sigma-1-receptor agonists in the treatment of SARS-CoV-2-infected patients. Recent studies show that sigma-1-receptor ligands attenuate SARS-CoV-2 replication [41, 42]. Via sigma-1 receptor chaperone activity, traditional CNS compounds (i.e., fluvoxamine, donepezil, ifenprodil) with potent sigma-1-receptor agonism may attenuate ER stress due to

not alter NGF-induced neurite outgrowth. Furthermore, NE-100, but not the sigma-2 receptor antagonist SM-21, significantly blocked ifenprodil's potentiating effects on NGF-induced neurite outgrowth [67]. These findings suggest that activation at sigma-1 receptors plays a role in the pharmacological effects of ifenprodil.

We reported some cases showing the beneficial effects of ifenprodil in post-traumatic stress disorder (PTSD) patients with a history of childhood abuse [68, 69]. Thus, it seems that ifenprodil may have beneficial effects in PTSD patients through sigma-1 receptor activation [70], although further study using a large sample size is needed.

Collectively, we propose that the sigma-1 receptor agonist ifenprodil might be a potential therapeutic drug for SARS-CoV-2-confirmed subjects. At present, a randomized open-label study of ifenprodil ( $20 \mathrm{mg}$ and $40 \mathrm{mg}$ ) in hospitalized patients with confirmed COVID-19 disease (ClinicalTrials.gov Identifier: NCT04382924) by Algernon Pharmaceutical (Vancouver, BC, Canada) is underway.
SARS-CoV-2 replication in cells, thus resulting in a blockade against inflammatory events (i.e., cytokine storm). Thus, early treatment using sigma-1-receptor agonists may block or delay clinical deterioration in individuals with SARS-CoV-2 infection. A slight modification is shown in Fig. 2, from Zhang et al. [1]

\section{Other candidate cutamesine and arketamine}

In 1996, Matsuno et al. [71] developed the novel and selective sigma-1 receptor agonist SA4503 (cutamesine) $\left(\mathrm{IC}_{50}=17.4 \mathrm{nM}\right.$ for the sigma-1 receptor and $\mathrm{IC}_{50}=1,784 \mathrm{nM}$ for the sigma-2 receptor). SA4503 significantly potentiated NGF-induced neurite outgrowth in PC12 cells, and the effects of SA4503 were antagonized by NE-100 [49]. We also reported that SA4503 improved $\mathrm{PCP}$-induced cognitive deficits in mice through sigma1-receptor activation [50]. In the stroke model, SA4503 stimulated recovery after stroke, which suggests that SA4503 may be a suitable therapeutic agent for stroke patients [72]. However, a phase II trial of SA4503 in patients with ischemic stroke showed no significant effects on functional end points [73]. Importantly, SA4503 (1 mg/ day and $3 \mathrm{mg} /$ day for 28 days) was safe and well tolerated in humans [73]. Therefore, it may be interesting to perform a clinical trial of SA4503 in SARS-CoV-2-infected patients. In addition, there are some additional sigma-1 receptor agonists for COVID-19 [74]. 
$(R, S)$-Ketamine, the NMDAR antagonist, has been widely used in the world as anesthetic [75]. Currently, $(R, S)$-ketamine is the most attractive antidepressant for severe depression since it produced rapid-onset and sustained antidepressant actions for patients with severe depression [76-78]. It is well known that $(R, S)$-ketamine can interact with sigma receptors including sigma- $1(\mathrm{Ki}=139.6 \mu \mathrm{M})$ and sigma-2 receptors $(\mathrm{Ki}=26.3 \mu \mathrm{M})[79]$ although its affinity at sigma-1 receptor is less potent than that of the aforementioned candidates (i.e., fluvoxamine, donepezil, ifenprodil, cutamesine). Furthermore, $(R, S)$-ketamine stimulated NGF-induced neurite outgrowth in PC12 cells through sigma-1 receptor activation [79]. We previously reported that $(R, S)$-ketamine produced a potent anti-inflammatory effects in treatmentresistant patients with depression [80]. Collectively, it is proposed that $(R, S)$-ketamine may have beneficial effects for patients infected with SARS-CoV-2 [81, 82]. At present, an open label study of $(R, S)$-ketamine in patients infected with SARS-CoV-2 (ClinicalTrials.gov Identifier: NCT04365985) at Williams Beaumont Hospital (Michigan, USA) is underway.

$(R)$-Ketamine (arketamine) is a more potent than $(S)$ ketamine (esketamine) at sigma-1 receptor [83, 84]. A PET study showed that $(R, S)$-ketamine interacts to sigma-1 receptor in non-human primate brain [85]. These data suggest that arketamine may stimulate at sigma-1 receptor in the human brain despite of low affinity. Importantly, side effects (i.e., psychosis and dissociation) of arketamine in humans are lower than $(R, S)$-ketamine and esketamine [86] since side effects of $(R, S)$-ketamine in humans are associated with esketamine [87]. Collectively, it is possible that arketamine may produce anti-inflammatory effects in individuals infected with SARS-CoV-2 if the data of $(R, S)$-ketamine in patients with COVID-19 are positive.

\section{Conclusion and future direction}

The two articles published in Nature and Science strongly suggest that the ER chaperone protein sigma-1 receptor plays an important role in the replication of SARS-CoV-2 in cells, and that the sigma- 1 receptor is a promising therapeutic target for COVID-19 infection [41, 42, 44, 74, 88]. However, which pharmacological activity (i.e., agonist or antagonist) of sigma-1 receptor ligands is responsible for the blockade of SARS-CoV-2 replication remains uncertain.

At present, it is easy to detect SARS-CoV-2 infection using a reverse transcription polymerase chain reaction (RTPCR) test. As discussed above, traditional CNS compounds, such as fluvoxamine, donepezil, and ifenprodil, exhibit potent agonistic activity at the sigma- 1 receptor. If we use these drugs to treat COVID-19-infected patients as quickly as possible after confirmation of SARS-CoV-2 infection, we might block or delay clinical deterioration. Now is the time to start clinical trials of sigma-1-receptor agonists in individuals infected with SARS-CoV-2, since these compounds have been used worldwide. Among these candidates, fluvoxamine is the most attractive drug for COVID-19 pandemic since it can be used from children to older adults.

Furthermore, the COVID-19 pandemic may be stressful for many people. Individuals infected with SARS-CoV-2 may present with psychiatric symptoms, such as fear, anxiety, depression, and suicide ideation. A recent study showed that survivors of COVID-19 appear to be at increased risk of psychiatric disorders such as anxiety disorders, insomnia and dementia [89]. Given these factors, fluvoxamine may be the most attractive candidate drug for COVID-19 treatment, since it has beneficial actions against anxiety and depression. Finally, we hope that the COVID-19 pandemic goes away soon.

Acknowledgements The author would like to thank my collaborators who are listed as the co-authors of our papers in the reference list. This work was supported in part by Japan Society for the Promotion of Science (to K.H., 17H04243 and 19H05203), Japan Agency for Medical Research and Development, AMED (to K.H., JP20dm0107119).

\section{Compliance with ethical standards}

Conflict of interest Dr. Hashimoto is the inventor of filed patent applications on "The use of $R$-ketamine in the treatment of psychiatric diseases", " $(S)$-norketamine and salt thereof as pharmaceutical", " $R$ ketamine and derivative thereof as prophylactic or therapeutic agent for neurodegeneration disease or recognition function disorder", "Preventive or therapeutic agent and pharmaceutical composition for inflammatory diseases or bone diseases", and " $R$-ketamine and its derivatives as a preventive or therapeutic agent for a neurodevelopmental disorder" by the Chiba University. Dr. Hashimoto received speaker honoraria from Abbott China. Dr. Hashimoto has received the research support from Dainippon Sumitomo, Otsuka, and Taisho.

\section{References}

1. Zhang J, Xie B, Hashimoto K (2020) Current status of potential therapeutic candidates for the COVID-19 crisis. Brain Behav Immun 87:59-73

2. Sanders JM, Monogue ML, Jodlowski TZ, Cutrell JB (2020) Pharmacologic treatments for coronavirus disease 2019 (COVID-19): a review. JAMA 323:1824-1836

3. Zhao M, Zhang J, Li H, Luo Z, Ye J, Xu Y, Wang Z, Ye D, Liu J, Li D, Wang M, Wan J (2020) Recent progress of antiviral therapy for coronavirus disease 2019. Eur J Pharmacol 24:173646. https ://doi.org/10.1016/j.ejphar.2020.173646

4. Abbasi J (2020) Existing drugs might treat COVID-19. JAMA 323:2239

5. Abbasi J (2020) Drug repurposing study pinpoints potential COVID-19 antivirals. JAMA 324:928

6. Touret F, Gilles M, Barral K, Nougairède A, van Helden J, Decroly E, de Lamballerie X, Coutard B (2020) In vitro screening of a FDA approved chemical library reveals potential inhibitors of SARS-CoV-2 replication. Sci Rep 10:13093 
7. Wang X, Guan Y (2021) COVID-19 drug repurposing: a review of computational screening methods, clinical trials, and protein interaction assays. Med Res Rev 41:5-28

8. Zhou Y, Wang F, Tang J, Nussinov R, Cheng F (2020) Artificial intelligence in COVID-19 drug repurposing. Lancet 2:e667-e676

9. Wu Y, Xu X, Chen Z, Duan J, Hashimoto K, Yang L, Liu C, Yang C (2020) Nervous system involvement after infection with COVID-19 and other coronaviruses. Brain Behav Immun $87: 18-22$

10. Rogers JP, Chesney E, Oliver D, Pollak TA, McGuire P, FusarPoli P, Zandi MS, Lewis G, David AS (2020) Psychiatric and neuropsychiatric presentations associated with severe coronavirus infections: a systematic review and meta-analysis with comparison to the COVID-19 pandemic. Lancet Psychiatry 7:611-627

11. Ellul MA, Benjamin L, Singh B, Lant S, Michael BD, Easton A, Kneen R, Defres S, Sejvar J, Solomon T (2020) Neurological associations of COVID-19. Lancet Neurol 19:767-783

12. Zhang J, Xu D, Xie B, Zhang Y, Huang H, Liu H, Chen H, Sun Y, Shang Y, Hashimoto K, Yuan S (2020) Poor-sleep is associated with slow recovery from lymphopenia and an increased need for ICU care in hospitalized patients with COVID-19: a retrospective cohort study. Brain Behav Immun 88:50-58

13. Zubair AS, McAlpine LS, Gardin T, Farhadian S, Kuruvilla DE, Spudich S (2020) Neuropathogenesis and neurologic manifestations of the coronaviruses in the age of coronavirus disease 2019: a review. JAMA Neurol 77:1018-1027

14. Hashimoto K (2020) Risk of neuropsychiatric disorders in offspring of COVID-19-infected pregnant women and nutritional intervention. Eur Arch Psychiatry Clin Neurosci 2:1-3. https:// doi.org/10.1007/s00406-020-01148-5

15. Zimmer A, Youngblood A, Adnane A, Miller BJ, Goldsmith DR (2020) Prenatal exposure to viral infection and neuropsychiatric disorders in offspring: a review of the literature and recommendations for the COVID-19 pandemic. Brain Behav Immun. https:// doi.org/10.1016/j.bbi.2020.10.024

16. Lenze E, Mattar C, Zorumski CF, Stevens A, Schweiger J, Nicol GE, Miller JP, Yang L, Yingling M, Avidan MS, Reiersen AM (2020) Fluvoxamine vs placebo and clinical deterioration in outpatients with symptomatic COVID-19. A randomized clinical trial. JAMA 324:2292-2300

17. Seymour CW, Bauchner H, Golub RM (2020) COVID-19 infection-preventing clinical deterioration. JAMA 324:2300

18. Harrison AG, Lin T, Wang P (2020) Mechanisms of SARS-CoV-2 transmission and pathogenesis. Trend Immunol 41:1100-1115

19. Santerre M, Arjona SP, Allen CN, Shcherbik N, Sawaya BE (2020) Why do SARS-CoV-2 NSPs rush to the ER? J Neurol 1:1-10. https://doi.org/10.1007/s00415-020-10197-8

20. Banerjee A, Czinn SJ, Reiter RJ, Blanchard TG (2020) Crosstalk between endoplasmic reticulum stress and anti-viral activities: a novel therapeutic target for COVID-19. Life Sci 255:117842

21. Aoe T (2020) Pathological aspects of COVID-19 as a conformational disease and the use of pharmacological chaperones as a potential therapeutic strategy. Front Pharmacol 11:1096

22. Köseler A, Sabirli R, Gören T, Türkçüer I, Kurt Ö (2020) Endoplasmic reticulum stress markers in SARS-COV-2 infection and pneumonia: case control study. In Vivo 34:1645-1650

23. Sureda A, Alizadeh J, Nabavi SF, Berindan-Neagoe I, Cismaru CA, Jeandet P, Łos MJ, Clementi E, Nabavi SM, Ghavami S (2020) Endoplasmic reticulum as a potential therapeutic target for covid-19 infection management? Eur J Pharmacol 882:173288

24. Martin WR, Eades CG, Thompson JA, Huppler RE, Gilbert PE (1976) The effects of morphine- and nalorphine-like drugs in the nondependent and morphine-dependent chronic spinal dog. J Pharmacol Exp Ther 197:517-532
25. Su TP (1982) Evidence for sigma opioid receptor: binding of $\left[{ }^{3} \mathrm{H}\right]$ SKF-10047 to etorphine-inaccessible sites in guinea-pig brain. J Pharmacol Exp Ther 223:284-290

26. Hanner M, Moebius FF, Flandorfer A, Knaus HG, Striessnig J, Kempner E, Glossmann H (1997) Purification, molecular cloning, and expression of the mammalian sigma ${ }_{1}$-binding site. Proc Natl Acad Sci USA 93:8072-8077

27. Hayashi T, Su TP (2007) Sigma-1 receptor chaperones at the ERmitochondrion interface regulate $\mathrm{Ca}^{2+}$ signaling and cell survival. Cell 131:596-610

28. Hayashi T, Tsai SY, Mori T, Fujimoto M, Su TP (2011) Targeting ligand-operated chaperone sigma-1 receptors in the treatment of neuropsychiatric disorders. Expert Opin Ther Targets 15:557-577

29. Alon A, Schmidt HR, Wood MD, Sahn JJ, Martin SF, Kruse AC (2017) Identification of the gene that codes for the $\sigma_{2}$ receptor. Proc Natl Acad Sci USA 114:7160-7165

30. Hashimoto K, Ishiwata K (2006) Sigma receptor ligands: possible application as therapeutic drugs and as radiopharmaceuticals. Curr Pharm Des 12:3857-3876

31. Hayashi T, Su TP (2008) An update on the development of drugs for neuropsychiatric disorders: focusing on the sigma-1 receptor ligand. Expert Opin Ther Targets 12:45-58

32. Hashimoto K (2009) Sigma-1 receptors and selective serotonin reuptake inhibitors: clinical implications of their relationship. Cent Nerv Syst Agents Med Chem 9:197-204

33. Niitsu T, Iyo M, Hashimoto K (2012) Sigma-1 receptor agonists as therapeutic drugs for cognitive impairment in neuropsychiatric diseases. Curr Pham Des 18:875-883

34. Hashimoto K (2013) Sigma-1 receptor chaperone and brainderived neurotrophic factor: emerging links between cardiovascular disease and depression. Prog Neurobiol 100:15-29

35. Hashimoto K (2015) Activation of sigma-1 receptor chaperone in the treatment of neuropsychiatric diseases and its clinical implication. J Pharmacol Sci 127:6-9

36. Albayrak Y, Hashimoto K (2017) Sigma-1 receptor agonists and their clinical implications in neuropsychiatric disorders. Adv Exp Med Biol 964:153-161

37. Schmidt HR, Kruse AC (2019) The molecular function of $\sigma$ receptors: past, present, and future. Trends Pharmacol Sci 40:636-654

38. Su TP (2019) Non-canonical targets mediating the action of drugs of abuse: cocaine at the sigma-1 receptor as an example. Front Neurosci 13:761

39. Maurice T (2020) Bi-phasic dose response in the preclinical and clinical developments of sigma-1 receptor ligands for the treatment of neurodegenerative disorders. Expert Opin Drug Discov 27:1-17. https://doi.org/10.1080/17460441.2021.1838483

40. Couly S, Goguadze N, Yasui Y, Kimura Y, Wang SM, Sharikadze N, Wu HE, Su TP (2020) Knocking out sigma-1 receptors reveals diverse health problems. Cell Mol Neurobiol. https://doi. org/10.1007/s10571-020-00983-3

41. Gordon DE, Jang GM, Bouhaddou M, Xu J, Obernier K, White KM, O'Meara MJ, Rezelj VV, Guo JZ, Swaney DL, Tummino TA, Hüttenhain R, Kaake RM, Richards AL, Tutuncuoglu B, Foussard H, Batra J, Haas K, Modak M, Kim M, Haas P, Polacco BJ, Braberg H, Fabius JM, Eckhardt M, Soucheray M, Bennett MJ, Cakir M, McGregor MJ, Li Q, Meyer B, Roesch F, Vallet T, Mac Kain A, Miorin L, Moreno E, Naing ZZC, Zhou Y, Peng S, Shi Y, Zhang Z, Shen W, Kirby IT, Melnyk JE, Chorba JS, Lou K, Dai SA, Barrio-Hernandez I, Memon D, Hernandez-Armenta C, Lyu J, Mathy CJP, Perica T, Pilla KB, Ganesan SJ, Saltzberg DJ, Rakesh R, Liu X, Rosenthal SB, Calviello L, Venkataramanan S, Liboy-Lugo J, Lin Y, Huang XP, Liu Y, Wankowicz SA, Bohn M, Safari M, Ugur FS, Koh C, Savar NS, Tran QD, Shengjuler D, Fletcher SJ, O'Neal MC, Cai Y, Chang JCJ, Broadhurst DJ, Klippsten S, Sharp PP, Wenzell NA, Kuzuoglu-Ozturk D, Wang HY, Trenker R, Young JM, 
Cavero DA, Hiatt J, Roth TL, Rathore U, Subramanian A, Noack J, Hubert M, Stroud RM, Frankel AD, Rosenberg OS, Verba KA, Agard DA, Ott M, Emerman M, Jura N, von Zastrow M, Verdin E, Ashworth A, Schwartz O, d'Enfert C, Mukherjee S, Jacobson M, Malik HS, Fujimori DG, Ideker T, Craik CS, Floor SN, Fraser JS, Gross JD, Sali A, Roth BL, Ruggero D, Taunton J, Kortemme T, Beltrao P, Vignuzzi M, García-Sastre A, Shokat KM, Shoichet BK, Krogan NJ (2020) A SARS-CoV-2 protein interaction map reveals targets for drug repurposing. Nature 583:459-468

42. Gordon DE, Hiatt J, Bouhaddou M, Rezelj VV, Ulferts S, Braberg H, Jureka AS, Obernier K, Guo JZ, Batra J, Kaake RM, Weckstein AR, Owens TW, Gupta M, Pourmal S, Titus EW, Cakir M, Soucheray M, McGregor M, Cakir Z, Jang G, O’Meara MJ, Tummino TA, Zhang Z, Foussard H, Rojc A, Zhou Y, Kuchenov D, Hüttenhain R, Xu J, Eckhardt M, Swaney DL, Fabius JM, Ummadi M, Tutuncuoglu B, Rathore U, Modak M, Haas P, Haas KM, Naing ZZC, Pulido EH, Shi Y, Barrio-Hernandez I, Memon D, Petsalaki E, Dunham A, Marrero MC, Burke D, Koh C, Vallet T, Silvas JA, Azumaya CM, Billesbølle C, Brilot AF, Campbell MG, Diallo A, Dickinson MS, Diwanji D, Herrera N, Hoppe N, Kratochvil HT, Liu Y, Merz GE, Moritz M, Nguyen HC, Nowotny C, Puchades C, Rizo AN, Schulze-Gahmen U, Smith AM, Sun M, Young ID, Zhao J, Asarnow D, Biel J, Bowen A, Braxton JR, Chen J, Chio CM, Chio US, Deshpande I, Doan L, Faust B, Flores S, Jin M, Kim K, Lam VL, Li F, Li J, Li YL, Li Y, Liu X, Lo M, Lopez KE, Melo AA, Moss FR 3rd, Nguyen P, Paulino J, Pawar KI, Peters JK, Pospiech TH Jr, Safari M, Sangwan S, Schaefer K, Thomas PV, Thwin AC, Trenker R, Tse E, Tsui TKM, Wang F, Whitis N, Yu Z, Zhang K, Zhang Y, Zhou F, Saltzberg D, QCRG Structural Biology Consortium, Hodder AJ, Shun-Shion AS, Williams DM, White KM, Rosales R, Kehrer T, Miorin L, Moreno E, Patel AH, Rihn S, Khalid MM, Vallejo-Gracia A, Fozouni P, Simoneau CR, Roth TL, Wu D, Karim MA, Ghoussaini M, Dunham I, Berardi F, Weigang S, Chazal M, Park J, Logue J, McGrath M, Weston S, Haupt R, Hastie CJ, Elliott M, Brown F, Burness KA, Reid E, Dorward M, Johnson C, Wilkinson SG, Geyer A, Giesel DM, Baillie C, Raggett S, Leech H, Toth R, Goodman N, Keough KC, Lind AL, Zoonomia Consortium, Klesh RJ, Hemphill KR, Carlson-Stevermer J, Oki J, Holden K, Maures T, Pollard KS, Sali A, Agard DA, Cheng Y, Fraser JS, Frost A, Jura N, Kortemme T, Manglik A, Southworth DR, Stroud RM, Alessi DR, Davies P, Frieman MB, Ideker T, Abate C, Jouvenet N, Kochs G, Shoichet B, Ott M, Palmarini M, Shokat KM, García-Sastre A, Rassen JA, Grosse R, Rosenberg OS, Verba KA, Basler CF, Vignuzzi M, Peden AA, Beltrao P, Krogan NJ (2020) Comparative host-coronavirus protein interaction networks reveal pan-viral disease mechanisms. Science 370:eabe9403

43. Tam SW, Cook L (1984) $\sigma$ opiates and certain antipsychotic drugs mutually inhibit (+)-[ $\left.{ }^{3} \mathrm{H}\right] \mathrm{SKF} 10,047$ and $\left[{ }^{3} \mathrm{H}\right]$ haloperidol binding in guinea pig brain membranes. Proc Natl Acad Sci USA 81:5618-5621

44. Harrison C (2020) Drug researchers pursue new lines of attack against COVID-19. Nat Biotechnol 38:655-664

45. Iyo M, Tadokoro S, Kanahara N, Hashimoto T, Niitsu T, Watanabe $\mathrm{H}$, Hashimoto K (2013) Optimal extent of dopamine $\mathrm{D}_{2}$ receptor occupancy by antipsychotics for treatment of dopamine supersensitivity psychosis and late-onset psychosis. J Clin Psychopharmacol 33:398-404

46. Okuyama S, Imagawa Y, Ogawa S, Araki H, Ajima A, Tanaka M, Muramatsu M, Nakazato A, Yamaguchi K, Yoshida M, Otomo S (1993) NE-100, a novel sigma receptor ligand: in vivo tests. Life Sci 53:PL285-PL290

47. Narita N, Hashimoto K, Tomitaka S, Minabe Y (1996) Interactions of selective serotonin reuptake inhibitors with subtypes of sigma receptors in rat brain. Eur J Pharmacol 307:117-119
48. Ishima T, Fujita Y, Hashimoto K (2014) Interactions of new antidepressants with sigma-1 receptor chaperons and their potentiation of neurite outgrowth in PC12 cells. Eur J Pharmacol 727:167-173

49. Nishimura T, Ishima T, Iyo M, Hashimoto K (2008) Potentiation of nerve growth factor-induced neurite outgrowth by fluvoxamine: role of sigma- 1 receptors, $\mathrm{IP}_{3}$ receptors and cellular signaling pathways. PLoS ONE 3:e2558

50. Hashimoto K, Fujita Y, Iyo M (2007) Phencyclidine-induced cognitive deficits in mice are improved by subsequent subchronic administration of fluvoxamine: role of sigma-1 receptors. Neuropsychopharmacology 32:514-521

51. Ishima T, Fujita Y, Kohno M, Kunitachi S, Horio M, Takatsu Y, Minase T, Iyo M, Hashimoto K (2009) Improvement of phencyclidine-induced cognitive deficits in mice by subsequent subchronic administration of fluvoxamine, but not sertraline. Open Clin Chem J $2: 7-11$

52. Iyo M, Shirayama Y, Watanabe H, Fujisaki M, Miyatake R, Fukami G, Shiina A, Nakazato M, Shiraishi T, Ookami T, Hashimoto K (2008) Fluvoxamine as a sigma-1 receptor agonist improved cognitive impairments in a patient with schizophrenia. Prog Neuropsychopharmacol Biol Psychiatry 32:1072-1073

53. Niitsu T, Shirayama Y, Fujisaki M, Hashimoto K, Iyo M (2010) Fluvoxamine improved cognitive impairments in a patient with schizophrenia. Prog Neuropsychopharmacol Biol Psychiatry 34:1345-1346

54. Niitsu T, Fujisaki M, Shiina A, Yoshida T, Hasegawa T, Kanahara N, Hashimoto T, Shiraishi T, Fukami G, Nakazato M, Shirayama Y, Hashimoto K, Iyo M (2012) A randomized, double-blind, placebo-controlled trial of fluvoxamine in patients with schizophrenia: a preliminary study. J Clin Psychopharmacol 32:593-601

55. Kishi T, Hirota T, Iwata N (2013) Add-on fluvoxamine treatment for schizophrenia: an updated meta-analysis of randomized controlled trials. Eur Arch psychiatry Clin Neurosci 263:633-641

56. Ishikawa M, Ishiwata K, Ishii K, Kimura Y, Sakata M, Naganawa M, Oda K, Miyatake R, Fujisaki M, Shimizu E, Shirayama Y, Iyo M, Hashimoto K (2007) High occupancy of sigma-1 receptors in the human brain after single oral administration of fluvoxamine: a positron emission tomography study using $\left[{ }^{11} \mathrm{C}\right] \mathrm{SA} 4503$. Biol Psychiatry 62:878-883

57. Hindmarch I, Hashimoto K (2010) Cognition and depression: the effects of fluvoxamine, a sigma-1 receptor agonist, reconsidered. Hum Psychopharmacol 25:193-200

58. Furuse T, Hashimoto K (2010) Sigma-1 receptor agonist fluvoxamine for delirium in intensive care units: report of five cases. Ann Gen Psychiatry 9:18

59. Rosen DA, Seki SM, Fernández-Castañeda A, Beiter RM, Eccles JD, Woodfolk JA, Gaultier A (2019) Modulation of the sigma-1 receptor-IRE1 pathway is beneficial in preclinical models of inflammation and sepsis. Sci Transl Med 11:eaau5266

60. Kato K, Hayako H, Ishihara Y, Marui S, Iwane M, Miyamoto M (1999) TAK-147, an acetylcholinesterase inhibitor, increases choline acetyltransferase activity in cultured rat septal cholinergic neurons. Neurosci Lett 260:5-8

61. Ishima T, Nishimura T, Iyo M, Hashimoto K (2008) Potentiation of nerve growth factor-induced neurite outgrowth in PC12 cells by donepezil: role of sigma-1 receptors and IP3 receptors. Prog Neuropsychopharmacol Biol Psychiatry 32:1656-1659

62. Kunitachi S, Fujita Y, Ishima T, Kohno M, Horio M, Tanibuchi Y, Shirayama Y, Iyo M, Hashimoto K (2009) Phencyclidineinduced cognitive deficits in mice are ameliorated by subsequent subchronic administration of donepezil: role of sigma-1 receptors. Brain Res 1279:189-196

63. Ishikawa M, Sakata M, Ishii K, Kimura Y, Oda K, Toyohara J, Wu J, Ishiwata K, Iyo M, Hashimoto K (2009) High occupancy of sigmal receptors in the human brain after single oral 
administration of donepezil: a positron emission tomography study using $\left[{ }^{11} \mathrm{C}\right] \mathrm{SA} 4503$. Int $\mathrm{J}$ Neuropsychopharmacol 12:1127-1131

64. Hashimoto K, London ED (1993) Further characterization of $\left[{ }^{3} \mathrm{H}\right]$ ifenprodil binding to sigma receptors in rat brain. Eur J Pharmacol 236:159-163

65. Hashimoto K, Mantione CR, Spada MR, Neumeyer JL, London ED (1994) Further characterization of $\left[{ }^{3} \mathrm{H}\right]$ ifenprodil binding in rat brain. Eur J Pharmacol 266:67-77

66. Hashimoto K, London ED (1995) Interactions of erythro-ifenprodil, threo-ifenprodil, erythro-iodoifenprodil, and eliprodil with subtypes of sigma receptors. Eur J Pharmacol 273:307-310

67. Ishima T, Hashimoto K (2012) Potentiation of nerve growth factor-induced neurite outgrowth in PC12 cells by ifenprodil: role of sigma-1 receptor and $\mathrm{IP}_{3}$ receptor. PLoS ONE 7:e37989

68. Kishimoto A, Kaneko M, Gotoh Y, Hashimoto K (2012) Ifenprodil for the treatment of flashbacks in female posttraumatic stress disorder patients with a history of childhood sexual abuse. Biol Psychiatry 71:e7-e8

69. Sasaki T, Hashimoto K, Okawada K, Tone J, Machizawa A, Tano A, Nakazato M, Iyo M (2013) Ifenprodil for the treatment of flashbacks in adolescent female posttraumatic stress disorder patients with a history of abuse. Psychother Psychosom 82:344-345

70. Hashimoto K, Sasaki T, Kishimoto A (2013) Old drug ifenprodil, new hope for PTSD with a history of childhood abuse. Psychopharmacology 227:375-376

71. Matsuno K, Nakazawa M, Okamoto K, Kawashima Y, Mita S (1996) Binding properties of SA4503, a novel and selective sigma-1 receptor agonist. Eur J Pharmacol 306:271-279

72. Ruscher K, Shamloo M, Rickhag M, Ladunga I, Soriano L, Gisselsson L, Toresson H, Ruslim-Litrus L, Oksenberg D, Urfer R, Johansson BB, Nikolich K, Wieloch T (2011) The sigma-1 receptor enhances brain plasticity and functional recovery after experimental stroke. Brain 134(Pt 3):732-746

73. Urfer R, Moebius HJ, Skoloudik D, Santamarina E, Sato W, Mita S, Muir KW, Cutamesine Stroke Recovery Study Group (2014) Phase II trial of the Sigma-1 receptor agonist cutamesine (SA4503) for recovery enhancement after acute ischemic stroke. Stroke 45:3304-3310

74. Vela JM (2020) Repurposing sigma-1 receptor ligands for COVID-19 therapy? Front Pharmacol 11:582310

75. Domino EF (2010) Taming the ketamine tiger. 1965. Anesthesiology 113:678-684

76. Zhang K, Hashimoto K (2020) An update on ketamine and its two enantiomers as rapid-acting antidepressants. Expert Opin Neurother 19:83-92

77. Hashimoto K (2019) Rapid-acting antidepressant ketamine, its metabolites and other candidates: a historical overview and future perspective. Psychiatry Clin Neurosci 73:613-627
78. Hashimoto K (2020) Molecular mechanisms of the rapid-acting and long-lasting antidepressant actions of $(R)$-ketamine. Biochem Pharmacol 177:113935

79. Robson MJ, Elliott M, Seminerio MJ, Matsumoto RR (2012) Evaluation of sigma $(\sigma)$ receptors in the antidepressant-like effects of ketamine in vitro and in vivo. Eur Neuropsychopharmacol 22:308-317

80. Yang JJ, Wang N, Yang C, Shi JY, Yu HY, Hashimoto K (2015) Serum interleukin-6 is a predictive biomarker for ketamine's antidepressant effect in treatment-resistant patients with major depression. Biol Psychiatry 77:e19-e20

81. Ortoleva J (2020) Consider adjunctive ketamine in mechanically ventilated coronavirus disease-2019 patients. J Cardiothorac Vasc Anesth 34:2580

82. Akinosoglou K, Gogos A, Papageorgiou C, Angelopoulos E, Gogos C (2020) Ketamine in COVID-19 patients: Thinking out of the box. J Med Virol. https://doi.org/10.1002/jmv.26681

83. Klepstad P, Maurset A, Moberg ER, Oye I (1990) Evidence of a role for NMDA receptors in pain perception. Eur J Pharmacol 187:513-518

84. Hustveit O, Maurset A, Oye I (1995) Interaction of the chiral forms of ketamine with opioid, phencyclidine, sigma and muscarinic receptors. Pharmacol Toxicol 77:355-359

85. Kortekaas R, Maguire RP, van Waarde A, Leenders KL, Elsinga PH (2008) Despite irreversible binding, PET tracer $\left[{ }^{11} \mathrm{C}\right]-\mathrm{SA} 5845$ is suitable for imaging of drug competition at sigma receptorsthe cases of ketamine and haloperidol. Neurochem Int 53:45-50

86. Leal GC, Bandeira ID, Correia-Melo FS, Telles M, Mello RP, Vieira F, Lima CS, Jesus-Nunes AP, Guerreiro-Costa LNF, Marback RF, Caliman-Fontes AT, Marques BLS, Bezerra MLO, DiasNeto AL, Silva SS, Sampaio AS, Sanacora G, Turecki G, Loo C, Lacerda ALT, Quarantini LC (2020) Intravenous arketamine for treatment-resistant depression: open-label pilot study. Eur Arch Psychiatry Clin Neurosci. https://doi.org/10.1007/s00406-02001110-5

87. Zanos P, Moaddel R, Morris PJ, Riggs LM, Highland JN, Georgiou P, Pereira EFR, Albuquerque EX, Thomas CJ, Zarate CA Jr, Gould TD (2018) Ketamine and ketamine metabolite pharmacology: insights into therapeutic mechanisms. Pharmacol Rev 70:621-660

88. Yesilkaya UH, Balcioglu YH, Sahin S (2020) Reissuing the sigma receptors for SARS-CoV-2. J Clin Neurosci 80:72-73

89. Taquet M, Luciano S, Geddes JR, Harrison P (2020) Bidirectional associations between COVID-19 and psychiatric disorder: retrospective cohort studies of 62354 COVID-19 cases in the USA. Lancet Psychiatry. https://doi.org/10.1016/S2215-0366(20)30462 $-4$ 